ORIGINAL ARTICLE

\title{
Structural investigation of the Short Dark Triad for Youths (13-16 years)
}

\author{
Agnieszka Klimczak (DD, A,B,C,D,E,F, Dorota Turska (D) A,B,D,E,F,G \\ Institute of Psychology, Maria Curie-Skłodowska University, Lublin, Poland
}

\section{BACKGROUND}

The classic three-factor structure of the Short Dark Triad Questionnaire (SD3) has been confirmed in studies on different populations. However, a few studies (including those on the Polish population) reveal some problem with the proposed SD3 structure. The main goal of the present study was to investigate the structure of the Short Dark Triad for Youths (SD3-Y) in a sample of subclinical Polish adolescents. The results obtained should be treated as comments on the inconsistencies that exist among classic and critical conceptualisations of the SD3 structure.

\section{PARTICIPANTS AND PROCEDURE}

Three studies were conducted: (1) adaptation of the Polish version of the SD3 in terms of linguistic and cognitive needs of adolescents $(N=45)$; (2) investigation of the structure of the SD3-Y $(N=405)$; (3) examination of the external validity of the SD3-Y $(N=325)$.

\section{RESULTS}

A series of confirmatory factor analyses, reliability analyses using $\omega$ coefficients as well as a correlation analysis between the Dark Triad traits and Big Five traits, aggression and self-esteem were conducted. No replication of the factor structure of the classic model was obtained. The bifactor Dark Dyad model with psychopathy and Machiavellianism as two dimensions best fits the data. The $\omega$ reliability coefficients were acceptable with the highest value for psychopathy. There was an admissible external validity level.

\section{CONCLUSIONS}

The Dark Triad as measured by SD3-Y comprises the Dark Dyad (psychopathy, Machiavellianism) and narcissism as a feature independent of the other two. Such data comply with the critical findings relating to the structure of the SD3 with a Polish adult population.

\section{KEY WORDS}

Dark Triad; SD3; factor analysis; adolescence

Corresponding Author - Prof. Dorota Turska, Institute of Psychology, Maria Curie-Skłodowska University,

5 Litewski Square, 20-080 Lublin, Poland, e-mail: dorota.turska@poczta.umcs.lublin.pl

AUthors' CONTRIBUtion - A: Study design - B: Data collection · C: Statistical analysis · D: Data interpretation ·

E: Manuscript preparation · F: Literature search · G: Funds collection

to Cite this ARTICLE - Klimczak, A., \& Turska, D. (2020). Structural investigation of the Short Dark Triad for Youths

(13-16 years). Current Issues in Personality Psychology, 8(3), 243-254.

RECEIVED 15.06.2020 - REVIEWED 03.07.2020 • ACCEPTED 28.08.2020 • PUBLISHED 05.10.2020 


\section{BACKGROUND}

The Dark Triad of personality was introduced nearly 20 years ago by Paulhus and Williams (2002) as a compilation of three malevolent personality traits: subclinical psychopathy, narcissism, and Machiavellianism. Before the construct of the Dark Triad was proposed, literature concerning each feature separately had been already abundant. Notwithstanding, most researchers (e.g. Jonason \& Kavanagh, 2010) have been studying all dark traits simultaneously since the authors' recommendations appeared (Paulhus \& Williams, 2002). Such an approach allows for capturing common aspects and those that are specific for each trait (Furnham, Richards, \& Paulhus, 2013; Paulhus \& Williams, 2002).

Initially, studies on the Dark Triad traits were conducted with the application of three different measures, i.e. predominantly the MACH IV (Christie \& Geis, 1970), the Narcissistic Personality Inventory (NPI; Raskin \& Hall, 1979), and the Self-Report Psychopathy Scale (SRP; Paulhus, Neumann, \& Hare, 2014). In total, these tools comprise over 100 items, and the wealth of testing items may prove arduous to the person examined, which can increase the risk of erroneous measurements. This problem was addressed by developing the Dirty Dozen (DD) scale, which comprises 12 items (Jonason \& Webster, 2010) and later the Short Dark Triad (SD3) made up of 27 items (Jones \& Paulhus, 2014). The Dirty Dozen scale was criticised by some researchers (Jones \& Paulhus, 2014; Lee et al., 2013; Maples, Lamkin, \& Miller, 2014; Miller et al., 2012) for an insufficient number of testing items in each subscale designed to measure a given personality trait (merely 4 items). "It would have been difficult to create a four-item psychopathy scale that tapped all components of psychopathy while also manifesting sufficient reliability" (Miller et al., 2012, p. 1048).

Another scale, i.e. the Short Dark Triad, which offered a bigger number of items in its subscales, was deemed to be more reliable (Jones \& Paulhus, 2014). Cultural adaptations of the tool indicated replicability of the classic factor-based structure and adequate psychometric properties (Argentinian adaptation: Salessi \& Omar, 2018; Croatian adaptation: Bogdanovic \& Cingula, 2015; French adaptation: Gamache, Savard, \& Maheux-Caron, 2018; German adaptation: Malesza, Ostaszewski, Büchner, \& Kaczmarek, 2017), although some researchers decreased the number of items so as to match a given model to the data available (Atari \& Chegeni, 2016; Pabian, De Backer, \& Vandebosch, 2015). Despite the popularity of this tool, three reports have appeared with a critical assessment of the factor structure of the scale (Persson, Kajonius, \& Garcia, 2017; Rogoza \& Cieciuch, 2017; Siddiqi, Shahnawaz, \& Nasir, 2020) on the US, Poland, and India samples respectively.
Persson et al. (2017) tested five potential models employing the exploratory factor analysis (EFA) and confirmatory factor analysis (CFA) followed by an external validity investigation. The results indicated that the best-fitting measurement model was a bifactor model with items from Machiavellianism and psychopathy modelled as one specific factor and narcissism as the other specific factor. This suggests that there is no clear differentiation between psychopathy and Machiavellianism as measured by the SD3. Moreover, a conclusion may be drawn that these constructs may, in fact, be equivalent.

In the Polish adaptation of the SD3 scale, Rogoza and Cieciuch (2017) assessed the Dark Triad structure and psychometric properties. They examined the external validity of the scale by testing seven hypothetical models with the application of the CFA. While psychopathy and Machiavellianism were closely linked with each other, the link between narcissism and the remaining traits of the Dark Triad proved to be the weakest. In view of the above, the authors proposed a bifactor model consisting solely of psychopathy and Machiavellianism (Dark Dyad). This model turned out to be the best fit for the data analysed.

Despite a very strong relation between Machiavellianism and psychopathy, specific aspects of each trait were found, i.e. impulse controllability for Machiavellianism and lack of such controllability in psychopathy. A matching two-factor conceptualization was supported in the study by Siddiqi et al. (2020). The results of the studies mentioned above indicate that there are inherent problems with the SD3 structure. That said, there seems to be a consensus with respect to the two-factor structure of the tool. The content of these factors remains a moot point. On the one hand, there are premises indicating that Machiavellianism and psychopathy are not distinguishable or that Machiavellianism is part of psychopathy (Persson et al., 2017). On the other hand (Rogoza \& Cieciuch, 2017), the results show that these are two distinct personality traits, and what distinguishes them is impulsiveness in the case of psychopathy and, in the case of Machiavellianism, an ability to control impulses required to achieve long-term aims. The nature of narcissism gives rise to some disagreement. Does this trait occur autonomously (Rogoza \& Cieciuch, 2017; Siddiqi et al., 2020) or is it a member of some constellation of traits (e.g. Dark Triad or Dark Dyad) (Persson et al., 2017)? In order to opt for one construct proposed by one group of authors or the others, further empirical verification is required.

Studies on the Dark Triad of personality are extremely popular, but mostly with respect to the adult population. In fact, studies on the Dark Triad traits and its role in adolescence are rather scarce. This can be attributed in part to a lack of linguistic and psychometric measures tailored to measure Dark Triad 
traits among young people. Pabian et al. (2015) used the SD3 scale in their studies on adolescent cyberaggression, but this tool was not subject to relevant adaptation procedures. Although the authors translated the measure from English to Dutch, they failed to make any changes in the content of the items so as to make them more intelligible to the age group under analysis. As a result of the verification of the factor structure of the scale and with due consideration for the CFA, five items were rejected (one item from the narcissism subscale, two items from the Machiavellianism subscale and two psychopathy items), since their values stood below 0.30 . No external validation of the measure was performed. A full adaptation of the SD3 scale was made by Pechoro et al. (2019), albeit with reference to at-risk youths only. The researchers claim that the scale is a reliable and consistent measure (Pechoro et al., 2019).

What should be underlined is a pressing need to undertake large scale studies to verify the psychometric properties of the SD3 with respect to middle adolescents. There are two reasons to support this proposition. Firstly, it is young people who are, to a larger degree than adults, prone to response fatigue, which is conducive to applying a brief measure of the Dark Triad. Secondly, a wide confirmation of the validity of the SD3 among adolescents would equip researchers with a reliable tool to measure malevolent and risky personality traits during the critical stage of development (Pechoro et al., 2019). Middle adolescence seems to be a key period for the unfolding of dark traits (Klimstra, Jelle, Sijtsema, Henrichs, \& Cima, 2014). Moreover, "clearly higher mean levels in older adolescents when compared to younger adolescents for all the dark features were determined" (Klimstra, Jeronimus, Sijtsema, \& Denissen, 2020, p. 16). Such data may, in turn, open up an opportunity to undertake corrective interventions early on, also for subclinical adolescents (Tsopelas \& Armenaka, 2012). It needs to be stressed that the SD3 has primarily been used with respect to "normal" communities (e.g. the student population), and it was originally designed as a subclinical measure (Jones \& Paulhus, 2014). To the best of our knowledge, no prior studies have examined psychometric properties, internal validity, and construct structure of the SD3 in a subclinical sample of early adolescents.

The main goal of the present study was to investigate the structure of the SD3-Y in a group of subclinical adolescents (13-16 years). The results obtained should be treated as a contribution to a debate on conceptualisations of the SD3 structure - proposed in the classic work by Jones and Paulhus (2014) and in critical studies (Persson et al., 2017; Rogoza \& Cieciuch, 2017; Siddiqi et al., 2020).

To achieve the goal, the SD3 scale was adapted so as to use the same on a sample of Polish subclinical adolescents (Study 1). Study 2 refers to the determi- nation of the SD3-Y structure. Instead of formulating a research hypothesis, a question was posed, i.e. "Does the Polish adaptation of the SD3-Y show the reproducibility of the classic factor-based structure?". Study 3 refers to the determination of the external validity of the initial version of the scale.

The application of external personality traits to describe the validity of measures is fairly common (Malesza et al., 2017). The validity of the SD3-Y was subsequently tested by verifying the correlation of variables such as Big Five personality traits, aggression dimensions, and a global measure of selfesteem. Such constructs proved important in prior studies with the original version of the Dark Triad assessment (Furnham et al., 2013). Many researchers seem to suggest (e.g. Lee \& Ashton, 2005) a negative correlation of each of the Dark Triad traits with conscientiousness and agreeableness on the one hand and positive with aggression on the other (Jonason, Foster, Kavanagh, Gouveia, \& Birkás, 2018). The relations with neuroticism remain unclear, and the results of the meta-analysis do not suggest any significant link (Muris, Meesters, \& Timmermans, 2013) nevertheless, there are studies that indicate positive links of each of the Dark Triad traits with neuroticism relative to angry hostility (DeShong, Helle, Lengel, Meyer, \& Mullins-Sweatt, 2017). Apparently, there is consistency among some reports regarding the relations of individual traits of the Dark Triad; for instance, narcissism exclusively correlates positively with extraversion and openness to experience (Rogoza, Wyszyńska, Maćkiewicz, \& Cieciuch, 2016). Moreover, the proposed positive links of narcissism with the self-esteem construct are also noticeable (Pechorro et al., 2019). The hypothesis formulated for the needs of Study 3 assumes the existence of significant correlations within the SD-3-Y, in line with the determined interdependencies (conscientiousness and agreeableness, aggression dimensions, and selfesteem constructs) Given some ambiguity of the reports heretofore, specific dependencies of the SD3-Y with neuroticism were not postulated.

A relevant permit for all stages of the study was obtained from the Research Ethics Committee in the Department of Psychology at Maria Curie-Sklodowska University in Lublin (Permit No. 22/2019). At each stage of the study the parents of the persons examined were duly informed about the aim and course of the study, and relevant written consent from the parents was obtained. Furthermore, the persons examined also declared their consent to participate in the study.

We used the CFA and verified several different models including the five models proposed by Persson et al. (2017): (1) a model with one DT dimension; (2) a correlated model with two factors in which one dimension is narcissism and the second is a combination of psychopathy and Machiavellianism items; 
(3) the Jones and Paulhus (2014) classic model; (4) a bifactor model with two specific factors; (5) a bifactor model with three specific factors; and one additional model suggested by Rogoza and Cieciuch (2017) (6) the bifactor Dark Dyad model with psychopathy and Machiavellianism as two dimensions.

\section{STUDY 1}

The study aimed at adapting the Polish version of the Short Dark Triad Questionnaire (Rogoza \& Cieciuch, 2017) to a study conducted among adolescents.

\section{PARTICIPANTS AND PROCEDURE}

A total of 45 adolescents (23 girls) who came from a medium sized town (Tarnów) participated in the study. The mean age of the participations was 13.84 $(S D=0.52)$. Given the age of the participants, purposive sampling was employed. It was assumed that the age of 13 is the lower threshold for the measure developed. The upper threshold was set at 16 , since a version for adults is generally used in personality questionnaires, e.g. NEO-FFI; cf. Polish adaptation Zawadzki, Strelau, Szczepaniak, and Śliwińska (1998).

The participants were provided with the original version of the SD3 (Rogoza \& Cieciuch, 2017) with one item removed, i.e. "I enjoy having sex with people I hardly know". The elimination of this item resulted from particularly careful considerations of the researchers, since having sex at this stage of adolescence (and casual sex in particular) is indicative of an anti-social pattern of behaviour associated with psychopathy. There is no doubt that such arbitrary removal of this item limited the essence of psychopathy, and, therefore, can be treated as a weakness of the study undertaken.

On the other hand, it seemed important to determine the 'ecological pertinence' of this item with respect to subclinical adolescents. To this end, 1) consultations were carried out with three researchers with over 20 years of experience in developmental psychology, 2) the results of the report entitled "Sexuality of Poles 2017" (Izdebski, 2017) concerning the average age for sexual initiation in Poland (approx. 18 years of age) were analysed, and 3) Polish legal provisions that regulate specific legal protection of minors in the area of their sexuality were brought to the fore (Article 197 of the Polish Criminal Code of 1997).

Consequently, a noticeable inappropriateness of this item for young adolescents in the Polish cultural milieu was confirmed. It was also assumed that the content of the item in question may cause some discomfort among the youngest study participants in the form of shame or anxiety. Failure to counteract such high mental costs of participation in scientific studies would certainly go beyond set ethical standards (Code of Ethics of a Psychologist, 1997).

A conversation was held with each participant to assess his/her understanding of each item of the SD3 scale by asking the following question: "Describe in your own words how you understand this." The items whose content was not clear to at least a third of the participants were deemed to be problematic. These included, inter alia, (1) "I have never gotten into trouble with the law" and (2) "Whatever it takes, I must get the important people on my side". These items were subsequently modified to read respectively as follows: (1) "I have never got into trouble with the police/municipal guards" and (2) "Whatever it takes, I must get those mates who rule in my class on my side". The preliminary version of the SD3 for youth (SD3-Y) so established comprised 26 items. The participants were to assess each item following the guidelines where 1 indicated strong disagreement and 5 - strong agreement. The reliability factors for individual scales were calculated and the results obtained are as follows: narcissism $(\omega=.66)$, psychopathy $(\omega=.71)$, and Machiavellianism $(\omega=.67)$; consequently, they are acceptable.

\section{STUDY 2}

The aim of this study was to verify the internal structure of the Polish version of the Short Dark Triad for Youth (SD3-Y-PL) questionnaire. All analyses were performed with the application of SPSS Statistics 24 and Amos 24.

\section{PARTICIPANTS AND PROCEDURE}

Four hundred and five adolescents (211 girls, 194 boys, groups with an equal number of representatives of the same sex: $\left.\chi^{2}(1)=0.71, p=.392\right)$ were recruited from three randomly selected primary schools (214 participants) and three randomly selected secondary schools (191 participants) from a large city (Warsaw), medium sized city (Lublin) and from a rural area (Radłów). The mean age of the participants was $14.43(S D=1.08)$. The study performed in the classroom consisted in responding to the preliminary version of the SD3-Y questionnaire; the average time of such responses was approx. $10 \mathrm{~min}$.

\section{Measure}

The Polish version of the Short Dark Triad Questionnaire for Youth comprising 26 items was used. The participants were to rate each item following a 5-point scale where 1 indicated strong disagreement and 5 - strong agreement. 


\section{RESULTS}

In order to verify the factor structure of the SD3-Y-PL questionnaire, a series of confirmatory factor analyses (CFA) was conducted by means of AMOS. Given the fact that the values of kurtosis and skewness of each item were not higher than 1.3, it was determined that the distribution of all items was quite symmetrical, and the assumption about multivariate normality was met; therefore, maximum likelihood (ML) was employed as the estimation method (see Mulaik, 2007). Some indices of the fit of the model to the data as proposed by Hu and Bentler (1999) were used. Cutoff criteria for fit indices are as follows: CFI > .95, RMSEA $<.06$. The value of $\chi^{2}$ was provided, but given the sensitivity of this coefficient to the sample size, it is not treated as a model fit criterion.

The analysis focused on six models, i.e. (1) a model with one DT dimension; (2) a correlated model with two factors in which one dimension is narcissism and the second is a combination of psychopathy and Machiavellianism items; (3) the three-factor classic model; (4) a bifactor model with two specific factors (one dimension being narcissism and the second being a combination of psychopathy and Machiavellianism items); (5) a bifactor model with three specific factors; and one additional model, (6) the bifactor Dark Dyad model with psychopathy and Machiavellianism as two dimensions.

Following a series of CFA, one item from the Machiavellianism subscale ("It's not wise to tell your secrets") was removed, since irrespective of the model tested, its factor value was lower than .04 and thus was practically negligible. A CFA was performed once again, and the results obtained are shown in Table 1.

The first model poorly fitted the data, which confirms that the Dark Triad should not be treated as a unidimensional construct. The second and the third model yielded very similar indicator values, i.e. $\mathrm{CFI}=.80-.81$, RMSEA $=.06$, which depart to a large extent from the cut-off criteria set for fit indexes. The second model featured two inter-correlated factors, one of which was narcissism and the other a combination of psychopathy and Machiavellianism items. The third model or the classic proposition of Jones and Paulhus (2014) was criticised for not being able to replicate the original factor structure. The current study proves the validity of this claim. In this model the correlation between narcissism and psychopathy and narcissism and Machiavellianism proved to be moderate ( $r=.54$ and $r=.47$ respectively), while the link between Machiavellianism and psychopathy was found to be very strong $(r=.94)$. These findings correspond with the results obtained by Rogoza and Cieciuch (2017) as well as Persson et al. (2017).

The next three proposals refer to bifactor models in which each item loads on the general factor (in this case the Dark Triad or Dark Dyad) and on the grouping/specific factors (psychopathy, Machiavellianism, and narcissism). "The bifactor model, in theory, allows one to directly explore the extent to which items reflect a common target trait and the extent to which they reflect a primary or subtrait" (Reise, Moore, \& Haviland, 2010, p. 5). If the items load more strongly on the grouping factor (i.e. narcissism) than on a bifactor (i.e. the Dark Triad), its content is unique in regards to the general trait.

The fourth model was presented in a paper by Persson et al. (2017) as best fitted to the data. Nevertheless, the current study shows that it is not so at all. Generally speaking, the items relating to psychopathy and Machiavellianism loaded more strongly on the bifactor, but the opposite trend emerged with respect to narcissism. The fifth model contains all the features of the triad as well as a bifactor trait. Statistical model fit data are basically the same as those for Model $4(\mathrm{CFI}=.87$, RMSEA $=.06)$, which proves that this solution does not offer a good fit. In this case psychopathy and Machiavellianism loaded more strongly on the general factor. With narcissism loaded more strongly than a bifactor, as in the previous models, the conclusion can be drawn that narcissism stands apart from the remaining triad traits,

Table 1

Model fit comparison of confirmatory factor analytic models in Study 1

\begin{tabular}{lcccc}
\hline Model & $\chi^{2}$ & $d f$ & CFI & RMSEA [90\% CI] \\
\hline Model (1) & 902.17 & 252 & .686 & $.080[.074-.086]$ \\
Model (2) & 656.47 & 251 & .804 & $.063[.057-.069]$ \\
Model (3) & 648.46 & 249 & .807 & $.063[.057-.069]$ \\
Model (4) & 513.67 & 228 & .865 & $.056[.049-.062]$ \\
Model (5) & 508.56 & 228 & .865 & $.055[.049-.062]$ \\
Model (6) & 187.75 & 75 & .918 & $.061[.050-.072]$ \\
\hline
\end{tabular}


i.e. psychopathy and Machiavellianism. The findings of Rogoza and Cieciuch (2017) are similar, and hence they proposed the last of the tested models or the Dark Dyad, which comprises solely psychopathy and Machiavellianism.

The sixth model (the Dark Dyad model) best fits the data. Given Hu and Bentler's (1999) rules for an excellent model fit, some statistical data are approval borderline cases (CFI $=.92)$, and some indicate a good model fit to the data (RMSEA = .06). The Dark Dyad was loaded more strongly than psychopathy and Machiavellianism, but, similar to the investigation conducted by Rogoza and Cieciuch (2017), some items loaded more strongly on the grouping factors. For Machiavellianism, these included item 9 "It is better to avoid arguing with other people because they may prove useful in future" and item 18 "There are things you should hide from others because they do not need to know". For psychopathy, these included item 8 "I avoid dangerous situations" and item 11 "People often say I'm out of control". The results indicate that although Machiavellianism and psychopathy have a lot in common, one can easily notice some specific aspects of these traits, i.e. strategic thinking in Machiavellianism and no impulse control in psychopathy.

\section{STUDY 3}

The aim of the study was to verify the external validity of the Short Dark Triad for Youth scale.

\section{PARTICIPANTS AND PROCEDURE}

Three hundred and twenty-five adolescents (151 girls, 174 boys; groups with an equal number of representatives of the same sex: $\left.\chi^{2}(1)=1.48, p=.224\right)$ were recruited from three randomly selected primary schools (176 participants) and two randomly selected secondary schools (149 participants) from a large city (Warsaw), medium sized city (Lublin) and from a rural area (Smęgorzów). The mean age of the participants was $14.99(S D=0.95)$. The study consisted in completing four questionnaires in the following order: 1) SD3-Y; 2) Rosenberg's Self-Esteem Scale; 3) Buss-Perry Aggression Questionnaire; and 4) Big Five Questionnaire - Children. It should be underlined that questionnaires 2-4 are used for studies on adolescents. The average time required to mark the answers was approx. $30 \mathrm{~min}$.

\section{Measures}

Dark Triad traits were assessed with the Short Dark Triad for Youth scale. The questionnaire comprised 25 items: 8 to measure psychopathy, 8 to measure
Machiavellianism, and 9 to measure narcissism (see Appendix). The participants had a 5-point scale to rate each item where 1 indicated strong disagreement and 5 - strong agreement. The reliability factors determined were as follows: narcissism $(\omega=.71)$, psychopathy $(\omega=.73)$, and Machiavellianism $(\omega=.65)$; their values are significantly higher than those obtained for the original scale version, which clearly supports the changes made.

The Big Five traits were measured by means of the Polish version of the Big Five Questionnaire Children (BFQ-C; Cieciuch, Toczyłowska-Niemiec, \& Barbaranelli, 2016). The questionnaire comprises 65 items [15 items measure each of the following traits: neuroticism $(\omega=.84)$, extraversion $(\omega=.79)$, openness $(\omega=.77)$, conscientiousness $(\omega=.80)$, and agreeableness $(\omega=.84)$ ]. The participants had a 5-point scale to assess each item where 1 indicated almost never and 5 - almost always.

Aggression was assessed by means of the Polish version of the Buss-Perry Aggression Questionnaire (BPQA; Aranowska \& Rytel, 2012). The questionnaire comprises 29 items broken down into 4 subscales: Physical Aggression (PA; 9 items; $\omega=.71$ ), Verbal Aggression (VA; 5 items; $\omega=.47)$, Anger (A; 7 items; $\omega=.53)$, and Hostility $(H ; 8$ items; $\omega=.66)$. The participants had a 5 -point scale to rate each item where 1 indicated extremely uncharacteristic of $m e$ and 5 extremely characteristic of me.

Self-esteem was measured by means of the Polish version of Rosenberg's Self-Esteem Scale (RSES; Łaguna, Lachowicz-Tabaczek, \& Dzwonkowska, 2007). The questionnaire comprises 10 items that evaluate individual self-esteem $(\omega=.77)$. The participants had a 4-point scale to assess each item, where 1 indicated strong agreement and 4 - strong disagreement.

\section{RESULTS}

The correlations between the Dark Triad traits as measured by SD3-Y and external variables such as the Big Five personality traits, different types of aggression symptoms and global self-esteem are shown in Table 2.

As regards the relationships with the Big Five personality traits, conscientiousness, two out of three traits of the Dark triad, i.e. psychopathy and Machiavellianism, correlate negatively with agreeableness and conscientiousness, a result compliant in part with the hypothesis under which each scale of the SD-3-Y retains relations with the listed personality traits. A positive correlation between narcissism and extraversion and openness to experience was fully confirmed.

Assuming a different analytical angle with respect to the relationships with the Big Five personality traits, it turns out that psychopathy was linked with 
Table 2

Correlation between the Dark Triad traits and the Big Five personality traits, symptoms of aggression and selfesteem

\begin{tabular}{lccc}
\hline Model & Psychopathy & Machiavellianism & Narcissism \\
\hline Big Five traits & & & \\
Neuroticism & $.42^{* *}$ & $.24^{* *}$ & .06 \\
Extraversion & $.15^{* *}$ & .08 & $.46^{* *}$ \\
Openness & -.11 & .01 & $.20^{* *}$ \\
Conscientiousness & $-.33^{* *}$ & $-.19^{* *}$ & .03 \\
Agreeableness & $-.39^{* *}$ & $-.32^{* *}$ & .01 \\
Aggression & & & $.28^{* *}$ \\
Physical aggression & $.56^{* *}$ & $.36^{* *}$ & $.24^{* *}$ \\
Verbal aggression & $.39^{* *}$ & $.31^{* *}$ & $.11^{*}$ \\
Anger & $.47^{* *}$ & $.33^{* *}$ & .11 \\
Hostility & $.36^{* *}$ & $.29^{* *}$ & $.42^{* *}$ \\
Self-esteem & -.05 & -.03 &
\end{tabular}

four traits. It correlated positively with neuroticism and extraversion, although the relation with extraversion was weak, and, as it was already indicated, negatively with agreeableness and conscientiousness. As regards Machiavellianism, a positive link was determined with neuroticism, and a negative one with agreeableness and conscientiousness. Narcissism was positively linked with only two features.

As regards the correlations between the Dark Triad traits and aggression, psychopathy and Machiavellianism were related with all types of aggression symptoms, and the strength of these relationships was higher for psychopathy. The weakest links were noted between narcissism and the three types of aggression: physical, verbal and anger. It can therefore be concluded that the results obtained comply with those assumed while formulating the hypothesis, and as initially suggested, narcissism was the only trait positively linked with global self-esteem.

\section{DISCUSSION}

The main goal of the present study was to investigate the structure of the SD3-Y in a group of subclinical adolescents (13-16 years). To achieve this goal, the Polish version of the scale to measure the Dark Triad personality traits for youth was adapted. The measure is linguistically appropriate to the cognitive capabilities of adolescents aged 13 plus, and its content does not depart from the original version of the SD3. Apparently, the validity of the SD3-Y is quite high.
As it was originally assumed regarding the relations with external variables, psychopathy and Machiavellianism are negatively linked to agreeableness and conscientiousness. There is a positive link with neuroticism, specifically in psychopathy. This result may seem unexpected taking into account the fact that a 'prototypical' psychopath is described as showing an absence of nervousness, and significant social 'potency.' On the other hand, a psychopath demonstrates considerable social ineptitude: unreliability, impulsiveness, and proneness to fits of anger (Isen, Baker, Kern, Raine, \& Bezdjian, 2018). Such observations reflect a highly complex or even a paradoxical structure of psychopathy, which has already been indicated in a seminal work by Cleckey (1941). As a result, the literature provides for two types of psychopathy. Primary psychopathy is characterised by callousness, manipulativeness, selfishness and lack of anxiety, whereas secondary psychopathy is related to engaging in antisocial behaviour because of extreme impulsivity and is neurotic in its nature (Levenson, Kiehl, \& Fitzpatrick, 1995). In the study of Rogoza and Cieciuch (2017), the SD3 dimension of psychopathy was almost equally related to both types of psychopathy measure: primary and secondary. One can conclude that because in the present study one item closely linked to boldness and maliciousness was removed, our subscale may largely measure secondary psychopathy, and that would explain the link with neuroticism. Nevertheless, secondary psychopathy is also characterised by introversion (Blackburn \& Fawcett, 1999), and 
our study demonstrated a positive relation with extraversion.

In view of the above, we are inclined towards justifying the results obtained by looking at the specificity of the ontogenetic stage of the participants of the study. Recent reports (e.g. Boduszek et al., 2019) suggest the existence of wide diversity of psychopathic traits in adults compared to children and adolescents. A set of psychopathic traits characteristic of subclinical adolescents indicates, inter alia, a particular affective responsiveness. This deficit pertains to the inability to understand other people's emotions, and such an unclear picture may cause anxiety and, in effect, lead to aggression. It may well be that during this stage of personality development, psychopathy and Machiavellianism manifest themselves in a way related closely to neuroticism, a conclusion that corresponds to the results of studies conducted on adolescents by Muris, Meesters, and Timmermans (2013) in which psychopathy and Machiavellianism also demonstrated such links. Narcissism, as we expected, is positively linked to openness and extraversion. All three traits of the triad are linked to various forms of aggression. The strength of such correlations is the greatest in the case of psychopathy and the smallest in the case of narcissism, which corresponds to the results of studies on adolescents conducted heretofore (Lau \& Marsee, 2013). As expected, only narcissism demonstrates a positive link to self-esteem.

The main aim of the present study was to investigate the structure of the SD3 and contribute to the discussion on the inconsistencies that exist among various conceptualisations. To this end, a series of confirmatory factor analyses were performed. Despite satisfactory external validity, it turns out that the measure continues to struggle with construct validity. The results of the current study indicate that the structure of the scale is not a three-factor one, as Jones and Paulhus (2014) assumed. As a matter of fact, the three reports (Persson et al., 2017; Rogoza \& Cieciuch, 2017; Siddiqi et al., 2020) suggested a bifactor model. Thus, our findings confirm a Dark Dyad model (Rogoza \& Cieciuch, 2017; Siddiqi et al., 2020; see also Miller, Hyatt, Maples-Keller, Carter, \& Lynam, 2017), which comprises psychopathy and Machiavellianism. We jointly tested six different models with special focus on bifactor models. The best-fitting model proved to be the bifactor model with psychopathy and Machiavellianism as specific factors. The CFA results concerning the bifactor model with all three traits as specific factors indicated independence of narcissism from the other two triad traits. In the studies on the bifactor model where narcissism was one specific factor and the other was a combination of psychopathy and Machiavellianism, Persson et al. (2017) confirmed that narcissism stood as an independent trait. This seems to confirm the view that while applying the SD3 measuring scale, we actually deal with the Dark Dyad. In the studies on the general D factor [Dark Factor of Personality (Moshagen, Hilbig, \& Zettler, 2018)], psychopathy and Machiavellianism were largely absorbed by the $\mathrm{D}$ factor while narcissism retained unique qualities that the general factor did not cover. This may result from the fact that narcissism as measured by the SD3 represents narcissistic admiration, and not narcissistic rivalry.

As shown in previous studies (Persson et al., 2017; Rogoza \& Cieciuch, 2017; Siddiqi et al., 2020), we also reported a strong correlation between psychopathy and Machiavellianism, which confirms that the SD3 scale has inherent problems with differentiating the two traits. In more recent studies of Rogoza and Cieciuch (2018) there is a suggestion that Machiavellianism as a trait may be merely an aspect of psychopathy. Nevertheless, the results of our studies show that although Machiavellianism and psychopathy overlap to some extent, these traits do represent specific phenomena, i.e. strategic thinking in Machiavellianism and no impulse control in psychopathy (cf. Rogoza \& Cieciuch, 2017).

\section{CONCLUSIONS}

The study described is yet another critical assessment of the structure of the Short Dark Triad Questionnaire. Such data comply with the critical findings relating to the structure of the SD3 with a Polish adult population. The results of the current research should not be ascribed to the specific nature of the Polish population, since similar findings were also obtained in other cultural milieu (Siddiqi et al., 2020).

Although the SD3 for Youth seems fully reliable, the interpretation of the measurement results obtained should be performed with caution in view of the issues relating to the replication of the classic factor structure.

\section{RefERENCES}

Aranowska, E., \& Rytel, J. (2012). Struktura czynnikowa kwestionariusza agresji Bussa i Perry'ego (BPQA) w populacji polskiej [Factorial structure of the Buss-Perry Aggression Questionnaire (BPQA) in Polish population]. Studia Psychologica, 12, 135-151.

Atari, M., \& Chegeni, R. (2016). Assessment of dark personalities in Iran: Psychometric evaluation of the Farsi translation of the Short Dark Triad (SD3-F). Personality and Individual Differences, 102, 111117. https://doi.org/10.1016/j.paid.2016.06.070

Blackburn, R., \& Fawcett, D. J. (1999). The Antisocial Personality Questionnaire: an inventory for assessing deviant traits in offender populations. European Journal of Psychological Assessment, 15, 14-24. https://doi.org/10.1027//1015-5759.15.1.14 
Boduszek, D., Debowska, A., Sherretts, N., Willmott, D., Boulton, M., Kielkiewicz, K., \& Hyland, P. (2019). Are prisoners more psychopathic than non-forensic populations? Profiling psychopathic traits among prisoners, community adults, university students, and adolescents. Deviant Behavior. https://doi.org/ 10.1080/01639625.2019.1665221

Bogdanovic, M., \& Cingula, D. (2015). Dark Triad of Croatian management students. Central European Business Review, 4, 30-47. https://doi.org/10.18267/j. cebr.136

Cieciuch, J., Toczyłowska-Niemiec, K., \& Barbaranelli, C. (2016). Kwestionariuszowy pomiar pięciu cech osobowości dzieci i dorastających. Polska adaptacja Big Five Questionnaire - Children (BFQ-C) [Questionnaire measurement of five personality traits in children and adolescents: a Polish adaptation of the Big Five Questionnaire - Children (BFQ-C)]. Psychologia Rozwojowa, 21, 73-85. https://doi.org/10.4467/20843879PR.16.011.5089

Christie, R., \& Geis, F. L. (1970). Studies in Machiavellianism. New York: Academic Press.

Furnham, A., Richards, S. C., \& Paulhus, D. L. (2013). The dark triad of personality: a 10-year review. Social and Personality Psychology Compass, 7, 199-216. https://doi.org/10.1111/spc3.12018

Cleckley, H. (1941). The mask of sanity: an attempt to reinterpret the so-called psychopathic personality. St. Louis, MO: Mosby.

DeShong, H. L., Helle, A. C., Lengel, G. J., Meyer, N., \& Mullins-Sweatt, S. N. (2017). Facets of the dark triad: Utilizing the five-factor model to describe Machiavellianism. Personality and Individual Differences, 105, 218-223. https://doi.org/10.1016/j. paid.2016.09.053

Gamache, D., Savard, C., \& Maheux-Caron, V. (2018). French adaptation of the Short Dark Triad: Psychometric properties and a head-to-head comparison with the Dirty Dozen. Personality and Individual Differences, 122, 164-170. https://doi.org/10.1016/j. paid.2017.10.027

Hu, L. T., \& Bentler, P. M. (1999). Cut-off criteria for fit indexes in covariance structure analysis: Conventional criteria versus new alternatives. Structural Equation Modeling, 6, 1-55. https://doi. org/10.1080/10705519909540118

Isen, J., Baker, L., Kern, M., Raine, A, \& Bezdjian, S. (2018). Unmasking the association between psychopathic traits and adaptive functioning in children. Journal of Individual Differences, 124, 57-65. https://doi.org/10.1016/j.paid.2017.11.043

Izdebski, Z. (2017). Seksualność Polaków 2017 [Sexuality of Poles 2017]. Retrieved from https://dimedic. eu/pl/wiedza/seksualnosc-polakow-2017-wynikiraportu [accessed November 11, 2019]

Jonason, P. K., Foster, J. D., Kavanagh, P. S., Gouveia, V. V., \& Birkás, B. (2018). Basic values and the dark triad traits. Journal of Individual Differ- ences, 39, 220-228. https://doi.org/10.1027/16140001/a000267

Jonason, P. K., \& Kavanagh, P. S. (2010). The dark side of love: Love styles and the Dark Triad. Personality and Individual Differences, 49, 606-610. https://doi. org/10.1016/j.paid.2010.05.030

Jonason, P. K., \& Webster, G. D. (2010). The dirty dozen: a concise measure of the dark triad. Psychological Assessment, 22, 420-432. https://doi. org/10.1037/a0019265

Jones, D. N., \& Paulhus, D. L. (2014). Introducing the Short Dark Triad (SD3): a brief measure of dark personality traits. Assessment, 21, 28-41. https:// doi.org/10.1177/1073191113514105

Klimstra, T. A., Jelle, J., Sijtsema, J. J., Henrichs, J., \& Cima, M. J. (2014). The Dark Triad of personality in adolescence: Psychometric properties of a concise measure and associations with adolescent adjustment from a multi-informant perspective. Journal of Research in Personality, 53, 84-92. https://doi.org/10.1016/j.jrp.2014.09.001

Klimstra, T. A., Jeronimus, B. F., Sijtsema, J. J., \& Denissen, J. J. A. (2020). The unfolding dark side: Age trends in dark personality features. Journal of Research in Personality, 85, e103915. https://doi.org/10.1016/j. jrp.2020.103915

Lau, K. L., \& Marsee, M. A. (2013). Exploring narcissism, psychopathy, and Machiavellianism in youth: Examination of associations with antisocial behavior and aggression. Journal of Child and Family Studies, 22, 355-367. https://doi.org/10.1007/ s10826-012-9586-0

Lee, K., \& Ashton, M. C. (2005). Psychopathy, Machiavellianism, and narcissism in the five-factor model and the HEXACO model of personality structure. Personality and Individual Differences, 38, 15711582. https://doi.org/10.1016/j.paid.2004.09.016

Lee, K., Ashton, M. C., Wiltshire, J., Bourdage, J. S., Visser, B. A., \& Gallucci, A. (2013). Sex, power, and money: Prediction from the dark triad and honesty-humility. European Journal of Personality, 27, 169-184. https://doi.org/10.1002/per.1860

Levenson, M. R., Kiehl, K. A., \& Fitzpatrick, C. M. (1995). Assessing psychopathic attributes in a noninstitutionalized population. Journal of Personality and Social Psychology, 68, 151-158. https://doi. org/10.1037/0022-3514.68.1.151

Łaguna, M., Lachowicz-Tabaczek, K., \& Dzwonkowska, I. (2007). Skala samooceny SES Morrisa Rosenberga - polska adaptacja metody [The Rosenberg Self-Esteem Scale: Polish adaptation of the scale]. Psychologia Spoteczna, 2, 164-176.

Malesza, M., Ostaszewski, P., Büchner, S., \& Kaczmarek, M. C. (2017). The adaptation of the Short Dark Triad personality measure - psychometric properties of a German sample. Current Psychology, 38, 855-864. https://doi.org/10.1007/s12144017-9662-0 
Maples, J. L., Lamkin, J., \& Miller, J. D. (2014). A test of two brief measures of the dark triad: the Dirty Dozen and Short Dark Triad. Psychological Assessment, 26, 326-331. https://doi.org/10.1037/a0035084

Miller, J. D., Few, L. R., Seibert, L. A., Watts, A., Zeichner, A., \& Lynam, D. R. (2012). An examination of the dirty dozen measure: a cautionary tale about the costs of brief measures. Psychological Assessment, 24, 1048-1053. https://doi.org/10.1037/ a 0028583

Miller, J. D., Hyatt, C. S., Maples-Keller, J. L., Carter, N. T., \& Lynam, D. R. (2017). Psychopathy and Machiavellianism: a distinction without a difference? Journal of Personality, 85, 439-453. https:// doi.org/10.1111/jopy. 12251

Moshagen, M., Hilbig, B., \& Zettler, I. (2018). The dark core of personality. Psychological Review, 125, 656688. https://doi.org 10.1037/rev0000111

Mulaik, S. (2007). There is a place for approximate fit in structural equation modelling. Personality and Individual Differences, 42, 883-891. https://doi. org/10.1016/j.paid.2006.10.024

Muris, P., Meesters, C., \& Timmermans, A. (2013). Some youths have a gloomy side: Correlates of the Dark Triad personality traits in non-clinical adolescents. Child Psychiatry \& Human Development, 44, 658-665. https://doi.org/10.1007/s10578-013-0359-9

Pabian, S., De Backer, C. J. S., \& Vandebosch, H. (2015). Dark Triad personality traits and adolescent cyber-aggression. Personality and Individual Differences, 75, 41-46. https://doi.org/10.1016/j. paid.2014.11.015.

Paulhus, D. L., Neumann, C. S., \& Hare, R. D. (2014). Manual for the Hare Self-Report Psychopathy scale. Toronto: Multi-Health Systems.

Paulhus, D. L., \& Williams, K. M. (2002). The dark triad of personality: Narcissism, Machiavellianism, and psychopathy. Journal of Research in Personality, 36, 556-563. https://doi.org/10.1016/S00926566(02)00505-6

Pechoro, P., Caramelo, V., Oliveira, J. P., Nunes, C., Curtis, S. R., \& Jones, D. N. (2019). The Short Dark Triad (SD3): Adaptation and psychometrics among at-risk male and female youths. Deviant Behavior, 40, 273-286. https://doi.org/10.1080/01639625.2017. 1421120

Persson, B. N., Kajonius, P. J., \& Garcia, D. (2017). Revisiting the structure of the Short Dark Triad. Assessment, 26, 3-16. https://doi.org/10.1177/107319111 7701192

Raskin, R. N., \& Hall, C. S. (1979). A narcissistic personality inventory. Psychological Reports, 45, 590. https://doi.org/10.2466/pr0.1979.45.2.590

Reise, S. P., Moore, T. M., \& Haviland, M. G. (2010). Bifactor models and rotations: Exploring the extent to which multidimensional data yield univocal scale scores. Journal of Personality Assessment, 92, 544559. https://doi.org/10.1080/00223891.2010.496477
Rogoza, R., \& Cieciuch, J. (2017). Structural investigation of the Short Dark Triad questionnaire in Polish population. Current Psychology, 38, 756-763. https://doi.org/10.1007/s12144-017-9653-1

Rogoza, R., \& Cieciuch, J. (2018). Dark Triad traits and their structure: an empirical approach. Current Psychology, 39, 1287-1302. https://doi.org/10.1007/ s12144-018-9834-6

Rogoza, R., Wyszyńska, P., Maćkiewicz, M., \& Cieciuch, J. (2016). Differentiation of the two narcissistic faces in their relations to personality traits and basic values. Personality and Individual Differences, 95, 85-88. https://doi.org/10.1016/j.paid.2016.02.038

Salessi, S., \& Omar, A. (2018). Psychometric properties of a scale to measure the dark side of personality. Estudos de Psicologia, 35, 159-170. https:// doi.org/10.1590/1982-02752018000200005

Siddiqi, N., Shahnawaz, M. G., \& Nasir, N. (2020). Reexamining construct validity of the Short Dark Triad (SD3) scale. Current Issues in Personality Psychology, 8, 18-30. https://doi.org/10.5114/cipp.2020.94055

Tsopelas, C., \& Armenaka, M. (2012). From conduct disorder in childhood to psychopathy in adult life. Psychiatriki, 23, 107-116.

Zawadzki, B., Strelau, J., Szczepaniak P., \& Śliwińska, M. (1998). Inwentarz osobowości NEO-FFI. Adaptacja polska [Personality inventory NEO-FFI. Polish adaptation]. Warszawa: Pracownia Testów Psychologicznych PTP. 
Sex Age

Please rate your agreement or disagreement for each item using the following scale

1 - I strongly disagree

2 - I disagree

3 - I neither agree or disagree

4 - I agree

5 - I strongly agree

1. People see me as a natural leader.

2. I like taking revenge on those who wish to rule.

3. I like cheating in order to get what I want.

4. I hate being at the centre of attention.

5. Revenge must be prompt and painful.

6. Whatever it takes, I must get those mates who rule in my class on my side.

7. Group tasks without me are usually boring.

8. I avoid dangerous situations.

9. It is better to avoid arguing with other people because they may prove useful in future.

10. I know I am one of a kind because everybody says so.

11. People often say that I am not in control of myself.

12. It pays to collect information that you can use against people later.

13. I like getting acquainted with important people.

14. It is true that I can be nasty at times.

15. You need to wait for the right time to get back at people.

16. I feel embarrassed when someone compliments me.

17. People who cross me always regret doing so.

18. There are things you should hide from others because they do not need to know.

19. I have been compared to famous people.

20. I have never got into trouble with the police/municipal guards.

21. It is essential that my plans benefit me, not others.

22. I am an average person.

23. Most people can be manipulated.

24. I insist on getting the respect I deserve.

25 . I will say anything to get what I want. 


\section{THE FINAL POLISH VERSION OF THE SD3 FOR YOUTH (SD3-Y)}

Płeć Wiek

Określ swoją zgodę lub niezgodę z każdym stwierdzeniem, używając następującej skali odpowiedzi:

1 - Zdecydowanie się nie zgadzam

2 - Raczej się nie zgadzam

3 - Trudno powiedzieć: ani się zgadzam, ani nie zgadzam

4 - Raczej się zgadzam

5 - Zdecydowanie się zgadzam

1. Ludzie uważają, że jestem urodzonym przywódcą.

2. Lubię mścić się na ludziach, którzy chcą rządzić.

3. Lubię oszukiwać, aby dostać to, czego chcę.

4. Nienawidzę być w centrum uwagi.

5. Zemsta musi nastąpić szybko i być bolesna.

6. Za wszelką cenę muszę mieć po swojej stronie takich kolegów, którzy rządzą w mojej klasie.

7. Zajęcia grupowe są zazwyczaj nudne beze mnie.

8. Unikam niebezpiecznych sytuacji.

9. Należy unikać kłótni z innymi ludźmi, ponieważ mogą się oni jeszcze kiedyś przydać.

10. Wiem, że jestem wyjątkowy, bo wszyscy mi o tym mówią.

11. Ludzie często mówią, że nie panuję nad sobą.

12. Warto jest zbierać informacje, których można będzie kiedyś użyć przeciwko innym ludziom.

13. Lubię nawiązywać znajomości z ważnymi ludźmi.

14. To prawda, że potrafię być podły dla innych.

15. Trzeba czekać na odpowiedni moment, aby odegrać się na innych.

16. Czuję się zawstydzony, kiedy ktoś mnie komplementuje.

17. Ludzie, którzy ze mną zadzierają, zawsze tego żałują.

18. Są rzeczy, które trzeba ukrywać przed innymi ludźmi, ponieważ nie muszą o tym wiedzieć.

19. Bywam porównywany do sławnych ludzi.

20. Nigdy nie miałem problemów z policją/strażą miejską.

21. Ważne jest, aby moje plany były dobre dla mnie, a nie dla innych.

22. Jestem przeciętną osobą.

23. Prawie z każdym człowiekiem można tak postępować, aby zrobił to, czego ja chcę.

24. Wymagam, aby okazywano mi szacunek, na który zasługuję.

25. Powiem wszystko, żeby tylko dostać to, czego chcę. 